\title{
Ocular surface adverse effects of ambient levels of air pollution
}

\author{
Efeitos adversos na superfície ocular relacionados à poluição ambiental
}

\author{
André Augusto Miranda Torricelli ${ }^{1}$, Priscila Novaes ${ }^{1}$, Monique Matsuda ${ }^{1}$, Milton Ruiz Alves ${ }^{1}$, Mário Luiz Ribeiro Monteiro ${ }^{1}$
}

\begin{abstract}
It is widely recognized today that outdoor air pollution can affect human health Various chemical components that are present in ambient pollution may have an irritant effect on the mucous membranes of the body, particularly those of the respiratory tract. Much less attention has been focused on the adverse effect on the ocular surface, despite the fact that this structure is even more exposed to air pollution than the respiratory mucosa since only a very thin tear film separates the corneal and conjunctival epithelia from the air pollutants. So far, clinical data are the more widespread tools used by ophthalmologists for assessing possible aggression to the ocular surface; however, clinical findings alone appears not to correlate properly with the complaints presented by the patients pointing out the need for further clinical and laboratory studies on the subject. The purpose of this study is to review signs and symptoms associated with chronic long-term exposure to environmental air pollutants on the ocular structures currently defined as the ocular surface and to review clinical and laboratory tests used to investigate the adverse effects of air pollutants on such structures. We also review previous studies that investigated the adverse effects of air pollution on the ocular surface and discuss the need for further investigation on the subject.
\end{abstract}

Keywords: Air pollutants/adverse effects; Environmental exposure; Eye manifestations; Cornea; Conjunctiva; Irritants/toxicity; Air pollution; Climate; Flourescent dyes/ diagnostic use

\begin{abstract}
RESUMO
Sabe-se hoje que a poluição ambiental pode afetar a saúde humana. Vários componentes químicos presentes na poluição atmosférica podem acarretar uma irritação nas mucosas, particularmente no trato respiratório. Pouca ênfase tem sido dada à superfície ocular, embora esta estrutura seja até mais exposta à poluição ambiental do que o trato respiratório visto que apenas uma fina camada de filme lacrimal separa a córnea e a conjuntiva dos poluentes presentes no ar. Atéo momento, a avaliação clínica éo método mais utilizado pelos oftalmologistas para se detectar uma possível agressão à superfície ocular; entretanto esta avaliação apenas não parece correlacionar-se com as queixas e sinais apresentados pelos pacientes demonstrando a necessidade de mais estudos clínicos e laboratoriais sobre o assunto. O objetivo deste estudo é revisar os sinais e sintomas associados à exposição crônica aos poluentes ambientais no ar nas estruturas oculares definidas atualmente como superfície ocular e revisar os testes clínicos e laboratoriais usados para investigar os efeitos adversos dos poluentes em tais estruturas. Também revisamos estudos prévios que analisaram os efeitos adversos da poluição do ar na superfície ocular e discutimos a necessidade de mais estudos sobre o assunto.
\end{abstract}

Descritores: Poluentes do ar/efeitos adverso; Exposição ambiental; Manifestações oculares; Córnea; Conjuntiva; Irritantes/toxicidade; Poluição do ar; Clima; Corantes fluorescentes/usodiagnóstico

\section{INTRODUCTION}

Air pollution is a complex mixture of solid and liquid particles suspended in the air (the so called particulate matter) that vary in size, composition and origin, and different types of gases such as ozone $\left(\mathrm{O}_{3}\right)$, nitrogen oxides $\left(\mathrm{NO}_{2}\right)$, volatile organic carbons, and carbon monoxide $(\mathrm{CO})^{(1,2)}$. In the recent years there has been considerable interest on the long and short-term effects of exposure to air pollution on human health. The growing industrialization and the progressive increase in the number of motor vehicles in large urban centers are the main causes of atmospheric pollution.

Previous studies have indicated that the short-time increase in pollutants levels, particularly of particulate material, have generally increased the mortality rate both in the USA ${ }^{(2,3)}$ and in Europe ${ }^{(4)}$. Two prospective cohort studies have also reported that the mortality risk was $26 \%$ greater for persons living in cities with elevated levels of air pollution ${ }^{(2,5)}$. An important increase on the prevalence of asthma and other respiratory symptoms has been attributed to such environmental abnormalities ${ }^{(6,7)}$.

The adverse effects of particulate matter and other environmental pollutants are therefore well known and their effects on the respiratory and circulatory systems have generally been stressed ${ }^{(8,9)}$.
However, only a few studies have systematically approached the effects of air pollution on the ocular system ${ }^{(10-13)}$. The purpose of this study is to review signs and symptoms associated to chronic longterm exposure to environmental air pollutants on the ocular structures currently defined as the ocular surface and to review clinical and laboratory tests used to investigate the adverse effects of air pollutants on such structures. We also review previous studies that investigated the adverse effects of air pollution on the ocular surface and discuss the need for further investigation on the subject.

\section{AIR POLLUTION}

Air pollution is the contamination of the indoor or outdoor environment by any chemical, physical or biological agent that modifies the natural characteristics of the atmosphere. Household combustion devices, motor vehicles, industrial facilities and forest fires are common sources of air pollution. Pollutants of major public health concern include particulate matter (PM), $\mathrm{CO}, \mathrm{O}_{3}, \mathrm{NO}_{2}$ and sulfur dioxide according to the World Health Organization $(\mathrm{WHO})^{(14)}$.

The WHO Air Quality Guidelines (AQG) are an international reference on the adverse effects of exposure to air pollutants on human health. WHO summarized the scientific knowledge on health

\footnotetext{
Submitted for publication: August 2,2011

Accepted for publication: October 16, 2011

1 Physician, Division of Ophthalmology and the Laboratory for Investigation in Ophthalmology (LIM-33), Universidade de São Paulo - USP - São Paulo (SP), Brazil.
}

Funding: No specific financial support was available for this study.

Disclosure of potential conflicts of interest: A.A.M.Torricelli, None; P.Novaes, None; M.Matsuda, None; M.R.Alves, None; M.L.R.Monteiro, None.

Correspondence address: André A. M. Torricelli. Av. Vereador Jose Diniz, 3300, conjunto 208 - São Paulo - SP - 04604-006 - Brazil - E-mail: andre_torri39@yahoo.com.br 
hazards related to air pollutants, providing risk estimates for exposure to air pollutants and recommending air quality guidelines. The latest global updated version of the WHO AQG was published in $2006^{(14,15)}$. In this guideline, the goals for controlling air pollution in order to protect human health are: PM less than $10 \mu \mathrm{m}$ in aerodynamic diameter $\left(\mathrm{PM}_{10}\right)$ levels lower than $25 \mu \mathrm{g} / \mathrm{m}^{3}$ in 24 hours and lower than $10 \mu \mathrm{g} / \mathrm{m}^{3}$ in 1 year averaging time; NO lower than $100 \mu \mathrm{g} / \mathrm{m}^{3}$ in 24 hours and lower than $40 \mu \mathrm{g} / \mathrm{m}^{3}$ in 1 year averaging time and $\mathrm{SO}_{2}$ level lower than $20 \mu \mathrm{g} / \mathrm{m}^{3}$ in 24 hours and lower than $500 \mu \mathrm{g} / \mathrm{m}^{3}$ in 10 minutes averaging time.

The WHO has also summarized the annual average concentrations of $\mathrm{PM}_{10}, \mathrm{NO}_{2}$ and $\mathrm{SO}_{2}{ }^{(14)}$ in different areas of the world (Table 1). In most European and North American cities, the $\mathrm{PM}_{10}$ annual average concentration levels are generally lower than $50 \mu \mathrm{g} / \mathrm{m}^{3}$. The highest levels of $\mathrm{PM}_{10}$ are found in Asia, Africa and Latin America. In Asia, PM is still the major and most important air pollutant, though in some large cities in China, a slight decrease in $\mathrm{PM}_{10}$ levels has been noted during the economic development that took place over the last few decades ${ }^{(16)}$. SO levels have been decreasing in most parts of the world, particularly in the United States and in Europe. In some Asian cities, (e.g., Bangkok, New Delhi, and Jakarta), the ambient SO, levels are low due to the low sulfur content of the fuel used there. On the other hand, in Chinese cities, although $\mathrm{SO}_{2}$ level has declined quite substantially, it is still relatively high. In larger cities in Latin America and Africa, there has also been a moderate decline in $\mathrm{SO}_{2}$ levels ${ }^{(14)}$. On the other hand, such a tendency has not been observed for trafficrelated air pollutants, i.e., $\mathrm{NO}_{2}$ and $\mathrm{O}_{3}$. On the contrary, in developing countries, levels of $\mathrm{NO}_{2}$ and $\mathrm{O}_{3}$ tend to increase due to the increased number of motor vehicles. Megacities where annual average $\mathrm{NO}_{2}$ exceeded the WHO air quality criteria of $40 \mu \mathrm{g} / \mathrm{m}^{3}$ were Beijing, Shanghai, Tokyo, Osaka, New York, Los Angeles, Sao Paulo and Mexico, while in New Delhi, Mumbai and Calcutta the annual average $\mathrm{NO}_{2}$ concentrations were lower than $40 \mu \mathrm{g} / \mathrm{m}^{3(15)}$ (Table 1).

Many time-series studies have explored the acute health effects associated with short-term exposure to airborne particulates ${ }^{(17)}$. In a meta-analysis, an increase of $10 \mu \mathrm{g} / \mathrm{m}^{3} \mathrm{PM}_{10}$ was associated with an increase in all-cause mortality of $0.46 \%$ in the United States (30 city studies), $0.62 \%$ in Europe (21 city studies), and $0.49 \%$ in Asia (4 city studies) ${ }^{(15)}$. The European APHEA-1 (Air Pollution and Health, a European Approach) study found a 1.3\% increase in daily deaths (95\% $\mathrm{Cl}$ 0.9-1.8) per $50 \mu \mathrm{g} / \mathrm{m}^{3}$ increase of $\mathrm{NO}_{2}{ }^{(18)}$. The effect remained statistically significant after adjusting for black smoke. Combined evidence from time-series studies show positive associations between daily mortality and ozone levels, independent of the effects of particulate matter. And finally, a meta-analysis on 95 United States urban communities studies showed that a $20 \mu \mathrm{g} / \mathrm{m}^{3}$ increase in ozone was associated with a $0.52 \%$ increase in total mortality and a $0.64 \%$ increase in cardiovascular and respiratory mortality ${ }^{(19)}$.

\section{EFFECTS OF AIR POLLUTION ON THE OCULAR SURFACE}

The ocular surface is composed of the surface and glandular epithelia of the cornea, conjunctiva, lacrimal gland, accessory lacri-

Table 1. Ranges of annual average concentrations of particulate matter less than $10 \mu \mathrm{m}$ in aerodynamic diameter $\left(\mathrm{PM}_{10}\right)$, nitrogen dioxide $\left(\mathrm{NO}_{2}\right)$, sulfur dioxide $\left(\mathrm{SO}_{2}\right.$ ) in different areas of the world (in $\mu \mathrm{g} / \mathrm{m}^{3}$ ) based on the World Health Organization ${ }^{14}$

\begin{tabular}{llcc}
\hline \multirow{2}{*}{ Region } & \multicolumn{3}{c}{ Annual average concentrations } \\
\cline { 2 - 4 } $\mathbf{P M}_{\mathbf{1 0}}$ & Nitrogen dioxide & Sulfur dioxide \\
\hline Africa & $40-150$ & $35-65$ & $10-100$ \\
Asia & $35-200$ & $20-75$ & $6-65$ \\
Canada/United States & $20-60$ & $35-70$ & $9-35$ \\
Europe & $20-70$ & $18-57$ & $8-36$ \\
Latin America & $30-129$ & $30-82$ & $40-70$ \\
\hline
\end{tabular}

mal glands and meibomian gland, the eyelashes with the glands of Moll and Zeiss and the nasolacrimal duct. Each of these structures is in constant contact with the air pollution and can be affected leading to a large variety of clinical signs and symptoms ${ }^{(20,21)}$. It is widely recognized today that outdoor air pollution can affect human health. Various chemical components present in ambient pollution may have an irritant effect on the mucous membranes, particularly those of the respiratory tract. Less attention has been focused on the ocular surface, although this structure is even more exposed to air pollution than the respiratory mucosa since only a very thin tear film separates the corneal and conjunctival epithelia from the air pollutants ${ }^{(22-24)}$.

Dysfunction of any component of the ocular surface system can lead to ocular symptoms through two interrelated mechanisms of abnormality: the hyper-osmolarity and the instability of the lacrimal film ${ }^{(25)}$. Lacrimal hyper-osmolarity may cause lesions on the epithelial surface by activating a series of inflammatory events on the ocular surface, which lead to the production of inflammatory mediators in the lacrimal film. Subsequent damage to the epithelium induces cell death due to apoptosis, loss of goblets cells and disorder of mucin expression, resulting in instability of the lacrimal film. This instability, on its hand, exacerbates the hyper-osmolarity of the eye surface forming a vicious cycle. This sequence of events is represented in figure $1^{(26)}$.

\section{Clinical evaluation of the ocular surface: SIGNS AND SYMPTOMS}

Traditionally, a combination of diagnostic tests has been used for assessing the degree of ocular symptoms and signs associated with ambient air pollution (Table 2). Along with the clinical history, the use of validated questionnaires for ocular symptoms is very helpful(27,28). There are several questionnaires available for grading symptoms severity, impact on daily activities and in quality of life. Such tools vary in size, reason for application, way of delivering (self-applied or through an interviewer), and extent of validation. The most commonly used questionnaires are: Ocular Surface Disease Index (OSDI), Canadian Dry Eye Epidemiology Study (CANDEES), Impact of Dry Eye on Everyday Life (IDEEL), National Eye-InstituteVisual Function Questionnaire (NEI-VFQ) e Women's Health Study Questionnaire(26).

On examination, elements used for ocular surface evaluation include: visual acuity assessment, external eye examination and slit lamp biomicroscopy. Additionally, diagnostic tests for evaluating instability of the lacrimal film, lesions of the ocular surface, and the flow of the watery tear portion are also carried out (Table 2). The instability of the lacrimal film is evaluated through the duration of tear break-up test (TBUT), a widespread method that involves the instillation of fluorescein dye in the eye and measuring the time

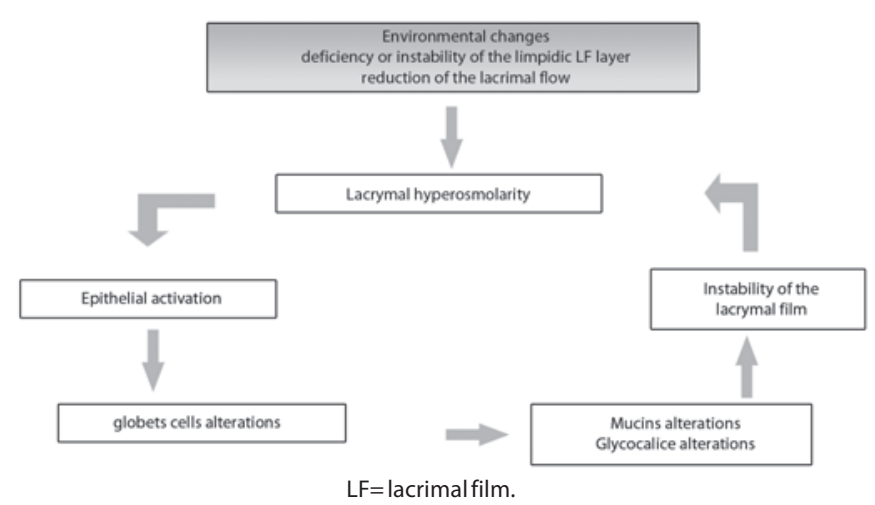

Figure 1. Inflammatory cycle of the ocular surface, modified from Dry Eye Work Shop. 
elapsed from the blinking until the tear film breaks up ${ }^{(26,29)}$. Values below 10 seconds are considered abnormal ${ }^{(30)}$. More recently, values of less than five seconds have been considered abnormal by some authors who suggest lower cut points when a smaller volume of fluorescein is instilled (5 micro-litres of fluorescein at $2 \%)^{(31)}$. Choosing lower values decreases the test sensibility and increases its specificity. Others tests to evaluate the tear film stability are: the interferometry, that measures the central precorneal tear film thickness noninvasively using an interference thin-film thickness measurement device ${ }^{(32-34)}$ and the meibomiometry, that uses a new laser meibometer to measure meibomian lipid levels on the lid margin by blotting meibomian gland oil into a piece of plastic and monitoring its transparency in order to calculate the amount of oil and its rate of delivery ${ }^{(35)}$. These tools are not commonly used in daily routine.

The lesions on the ocular surface are normally evaluated through staining with vital dyes such as: rose Bengal (Figure 2), green lissamine, and fluorescein. Abnormal patterns of cornea or conjunctiva

Table 2. Diagnostic procedures for assessing the ocular surface
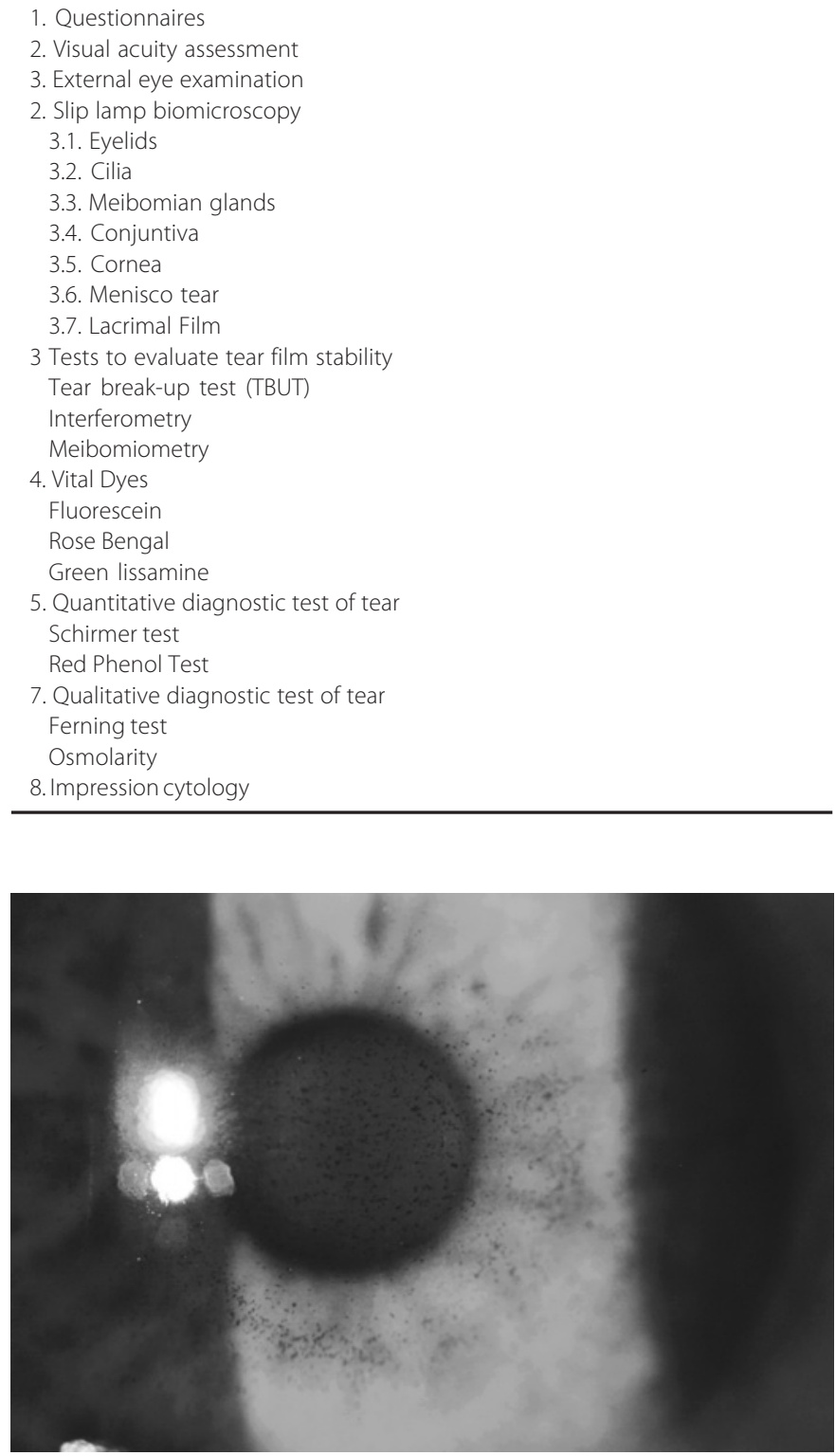

Figure 2. Ocular surface lesion staining with rose Bengal. staining are observed at slit lamp examination. The fluorescein dye is well tolerated. The results of such test may be variable. Testing with rose Bengal dye reveals more consistent results although it causes greater ocular discomfort when compared to green lissamine, which presents a staining pattern similar to rose Bengal and it is as well tolerated as fluorescein ${ }^{(26,36,37)}$. Three systems for the quantification of the impregnation patterns are currently in use: the Van Bijsterveld system $^{(38)}$, the Oxford system ${ }^{(39)}$ and the system developed by the CLEK study ${ }^{(40)}$. The Oxford and CLEK studies use a more detailed quantification than the van Bijsterveld system, allowing for a more accurate detection of ocular surface abnormalities. No previous study has defined which is the best quantification system ${ }^{(26)}$.

As far as the aqueous portion is concerned, it is normally assessed by the Schirmer's test ${ }^{(26)}$. According to this test, when performed without topical anesthesia, less than $10 \mathrm{~mm}$ after 5 minutes in at least one eye is a criterion for diagnosing dry eye $\mathrm{e}^{(41)}$. Many clinicians regard the Schirmer test as unduly invasive and of little value for mild to moderate dry eyes. Other less invasive methods to assess the adequacy of tear production have been developed. The phenol red thread test is one such test and is commercially available. A cotton thread impregnated with phenol red dye is used. Phenol red is $\mathrm{pH}$ sensitive and changes from yellow to red when wetted by tears. The crimped end of a $70 \mathrm{~mm}$ long thread is placed in the lower conjunctival fornix. After 15 seconds, the length of the color change on the thread, indicating the length in millimeters of the thread wetted by the tears. Normal measurements are between $9 \mathrm{~mm}$ and $20 \mathrm{~mm}^{(42)}$. Patients with dry eyes have wetting values of less than $9 \mathrm{~mm}$.

The tear ferning test reflects the tear composition and offers another way to assess tear film integrity and quality. When mucus is permitted to air dry on a microscope slide, a specific crystallization and arborisation (fern) occurs, which has been termed "ferning". Rolando(43) identified differences among tear ferning patterns and described a classification system that tear ferning became a useful diagnostic tool. The author described four qualitative categories, which depended on the presence, the size and density of the ferns observed (Figure 3). Rolando found that normal tear films often demonstrated a Type I or II pattern (with lots of ferning), whereas patients with keratoconjunctivitis sicca (KCS) had Type III and IV tear ferning patterns (in which there was scarce or absent ferning). Although Rolando's classification system ${ }^{(43,44)}$ is subjective, it remains simple, quick, repeatable and has a short learning curve.

An increase in tear osmolarity is a hallmark of dry eye disease and is thought to be the central mechanism in the pathogenesis of ocular surface damage, as noted in the Dry Eye WorkShop Report (DEWS) ${ }^{(25)}$. Tear osmolarity has been reported to be the single best marker for dry eye disease ${ }^{(25)}$. Successful measurement of tear osmolarity was thought to necessitate collection of a large amount of tears. With technological advances in its measurement, tear osmolarity is now more feasible to use in assessing dry eye. Others common extrinsic problems such as vitamin A deficiency and allergies $^{(25)}$ or contact lens wear have also shown increased tear osmolarity ${ }^{(45-47)}$.

Finally, impression cytology is a non-invasive laboratory method for assessing the ocular surface, which includes the epithelium of the conjunctiva and the cornea ${ }^{(48)}$. The filter paper, when applied on the corneo-conjunctiva surface, removes samples that contain from one to three layers of epithelial cells and preserves the morphological characteristics of the collected cells ${ }^{(49)}$.

\section{Studies inVestigating ocular adVerse effects OF AIR POLLUTION}

In recent years, patients seeking ophthalmic examination with subjective symptoms of eye irritation such as foreign body sensation, burning, itching, photophobia and whimpering has become a common occurrence. However, most often clinical examination does not reveal a corresponding ocular abnormality ${ }^{(10)}$. 


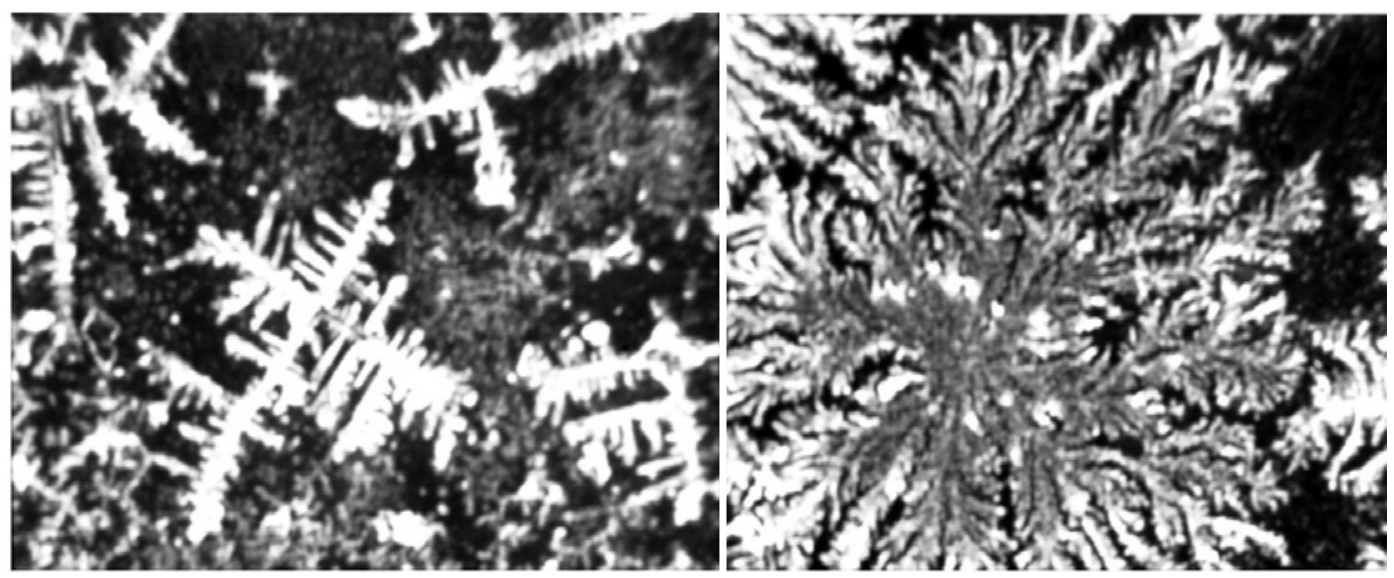

Figure 3. Tear crystallization test in patients with dry eye (left) and in normal volunteers (right). The greater the number of branches during crystallization (ferning test) and more leafy, the better the quality of the tears (courtesy of Dr. Richard Hida and Dr. Ruth Santo).

Several studies have tried to relate these subjective symptoms to a possible subclinical ocular inflammation and to a prolonged exposition to air pollution ${ }^{(10,13,50)}$. Saxena et al., ${ }^{(13)}$ compared two groups of 500 healthy volunteers living in New Delhi and found greater instability of the lacrimal film, as evaluated both by the lacrimal film time of rupture test and the Schirmer's test, in individuals showing a daily routine of air pollution exposition. No significant difference was found, however, when Rose Bengal staining was evaluated ${ }^{(13)}$. According to this study, climatic conditions appear to have a very significant effect on the ocular surface. High levels of subclinical ocular surface abnormalities were found in persons traveling in highly polluted areas. These high levels may represent a reason for concern if they do reflect the ocular status of the general populations living in large metropolis such as Delhi.

On the other hand, Versura et al., ${ }^{(10)}$ through the analysis of 100 individuals exposed to different levels of environmental pollution, did not find statistically significant difference in the lacrimal film rupture tests and the Schirmer's test in different groups of individuals. On the contrary and in disagreement with the previously mentioned study, the results of the tests were not significantly related to high levels of pollution. However, in this study, the results of impression cytology studies from the ocular surface documents for the first time showed the occurrence of inflammation and indicated that it may be greater in individuals who are more exposed to the pollution. This finding is quite remarkable in that it shows the importance of cytological analysis in those cases where the clinical observation does not lead to a diagnosis, in addition it suggests that one should not rely solely on clinical signs only, at least in cases of questionable etiology.

It is known from the literature that direct exposition of the ocular surface to various irritant substances causes neurogenic conjunctive vasodilatation and immediate whimpering ${ }^{(51)}$. Chemical substances may solubilize in lacrimal film and, possibly, sensitize specific lymphocytes subpopulations, as it was already shown with the $\mathrm{SO}_{2}$ in the bronchial mucous membrane, producing a chronic inflammation after a prolonged exposition. The inflammation seems to influence the epithelial differentiation and the density of the globets cells through an yet unknown mechanism ${ }^{(52)}$.

According to the last global definition dry eye is a multifactorial disease of tears and ocular surface that results in symptoms of discomfort, visual disturbance, and tear film instability with potential damage to the ocular surface. It is accompanied by increased osmolarity of the tear film and inflammation of the ocular surface ${ }^{(25)}$. Various factors may work independently or interact with each other, as a consequence, complementary diagnostic test are usually performed, to evaluate beyond the clinical picture.
Hyperplasia of the goblets cells in response to increased levels of air pollution levels has already been described in literature. Novaes et al., ${ }^{(12)}$ evaluated the effects of the atmospheric pollution on the ocular surface, by comparing individuals exposed to different levels of environmental pollution. Twenty-nine volunteers were recruited from two distinct places: São Paulo, the capital and most industrialized city in the State São Paulo and Divinolândia, a small town from the São Paulo State countryside where half of the population lives in the rural area. $\mathrm{NO}_{2}$ was used as an indicator of exposition to environmental pollution. Individual measurement of exposition to the different levels of $\mathrm{NO}_{2}$ was obtained during seven days. The study showed that the subjects living in the city of São Paulo were exposed to significantly greater doses of $\mathrm{NO}_{2}$ (mean $32.47 \mu \mathrm{g} / \mathrm{m}^{3}$, SD 9.83) than those from Divinolândia (mean $19.33 \mu \mathrm{g} / \mathrm{m}^{3}$, SD 5.24) and the amount of goblets cells showed an increase proportional to the $\mathrm{NO}_{2}$ exposition with a dose-response pattern ${ }^{(11)}$. In this study a positive and significant association between exposure to air pollution and goblet cell hyperplasia in human conjunctiva was observed (Figure 4); the combination of simple measurements of exposure and impression cytology was shown to be an effective and non-invasive approach to characterize human response to ambient levels of air pollution.

In another study, the same group evaluated 55 healthy volunteers recruited among the staff of the General Clinics Hospital of the University of São Paulo Medical School. The purpose of this study was to evaluate the effects of exposure to air pollution produced by traffic sources on the ocular surface, by comparing subjective ocular complains and results of routine clinical tests with individual measures of exposure to air pollution and also evaluate the importance of these measures as potential bioindicators of air pollution. This was the first study that has associated subjective measurements of ocular symptoms and disease specific quality of life and clinical assessment to individual measures of exposure to ambient air pollution. The clinical questionnaires were computed across quartiles of $\mathrm{NO}_{2}$ exposure into four quartiles (Q1: 9.9-20.0 $\mu \mathrm{g} / \mathrm{m}^{3}$; Q2: 20.1$26.0 \mu \mathrm{g} / \mathrm{m}^{3}$; Q3: 26.1-35.0 $\left.\mu \mathrm{g} / \mathrm{m}^{3} ; \mathrm{Q} 4:>35 \mu \mathrm{g} / \mathrm{m}^{3}\right)$, a clear doseresponse pattern was detected; besides a significant correlation between $\mathrm{NO}_{2}$ quartiles and ocular irritation was observed ${ }^{(12)}$

All these results serve as a basis for the hypothesis that the exposition to air pollution induces alterations on the ocular surface secondary to an environmental aggression. However, although many individuals have relevant clinical symptoms due to air pollution, it must be stressed that some people cohabit adequately with such pollution, presenting few symptoms or even none before such very same aggression. Therefore it is possible that these individuals have adaptation mechanisms that sufficed for defense or even for the 


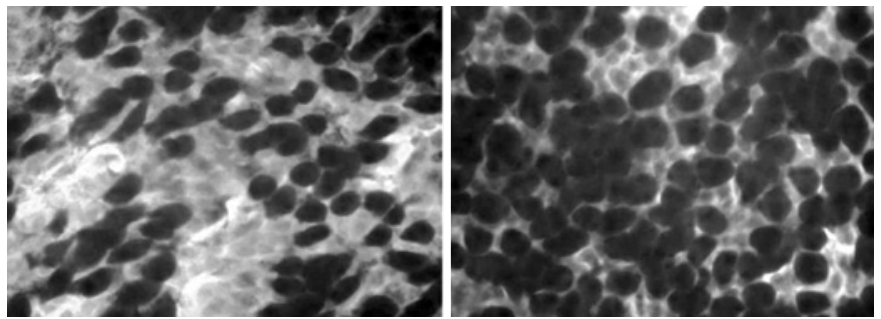

Figure 4. Impression cytology samples showing cellular hyperplasia response to air pollution.

functional recovery when submitted to elevated levels of environmental pollution.

So far, clinical data are the more widespread tools used by ophthalmologists for assessing a possible aggression to the ocular surface; however, this evaluation alone seems not to correlate with the complaints and signs presented by the patients. Therefore, more objective data, such as the evaluation of the goblets cells or other objective inflammation measurements for the evaluation of the ocular surface seem necessary.

The role and the exact mechanism through which the environmental pollution contributes to the several ocular complaints seem yet to be a large field for study and research.

\section{FINAL CONSIDERATIONS}

In recent years, a dramatic increase in atmospheric pollution in large cities throughout the world has led to an increased concern regarding its adverse effects on health. As the eye is constantly exposed to the external environment individuals living in areas with high concentrations of pollutants frequently have ocular complaints related to tear film abnormalities and ocular surface pathology with symptoms such as watering, burning and redness of the eyes. However, the ocular mechanisms involved in chronic long-term exposure to a high degree of environmental pollution are still largely unclear.

As pointed out in this review while many studies have been performed investigating air pollution adverse effects towards the circulatory and respiratory system, similar studies directed to understanding the effect on the ocular surface are very scarce. The marked advances in understanding the physiology and in the methods of assessing the ocular surface in recent years are therefore in striking contrast with the lack of studies investigating air pollution effect on ocular surface both of healthy subjects as well as diseased patients. We hope that in the near future studies can be performed to clarify such issues, to better understand the clinical and laboratorial abnormalities of the ocular surface, the relationship between ocular and systemic effects as well as possible mechanism of adaptations involved in the important subject of adverse effects of air pollution in the ocular surface.

\section{REFERENCES}

1. Perez L, Rapp R, Kunzli N. The Year of the Lung: outdoor air pollution and lung health. Swiss MedWkly. 2010;140:w13129.

2. Dockery DW, Pope CA $3^{\text {rd }}$, Xu X, Spengler JD, Ware JH, Fay ME, et al. An association between air pollution and mortality in six U.S. cities. N Engl J Med. 1993;329(24):1753-9. Comment in: NEngl J Med. 1993;329(24):1807-8. N Engl J Med. 2004;350(2):198-9. N Engl J Med. 1994;330(17): $1237-8$.

3. Pope CA $3^{\text {rd }}$, Schwartz J, Ransom MR. Daily mortality and PM10 pollution in Utah Valley. Arch Environ Health. 1992;47(3):211-7.

4. Katsouyanni K, Touloumi G, Spix C, Schwartz J, Balducci F, Medina S, et al. Short-term effects of ambient sulphur dioxide and particulate matter on mortality in 12 European cities: results from time series data from the APHEA project. Air Pollution and Health: a European Approach. BMJ. 1997;314(7095):1658-63. Comment in: BMJ. 1998;316(149):1982.

5. Pope CA $3^{\text {rd }}$, Thun MJ, Namboodiri MM, Dockery DM, Evans JS, Speizer FE, et al. Particulate air pollution as a predictor of mortality in a prospective study of U.S. adults. Am J Respir Crit Care Med. 1995;151(3 Pt 1):669-74.
6. Bucchieri F, Puddicombe SM, Lordan JL, Richter A, Buchanan D, WIlson SJ, et al. Asthmatic bronchial epithelium is more susceptible to oxidant-induced apoptosis. Am J Respir Cell Mol Biol. 2002;27(2):179-85.

7. Leitte AM, Schlink U, Herbarth O, Wiedensohler A, Pan XC, Hu M, et al. Size segregated particle number concentrations and respiratory emergency room visits in Beijing, China. Environ Health Perspect. 2011;119(4):508-13,

8. Barnett AG, Williams GM, Schwartz J, Best TL, Neller AH, Petroeschevsky AL, et al. The effects of air pollution on hospitalizations for cardiovascular disease in elderly people in Australian and New Zealand cities. Environ Health Perspect. 2006;114(7):1018-23.

9. Pope CA $3^{\text {rd }}$, Burnett RT, Thun MJ, Calle EE, Krewski D, Ito K, et al. Lung cancer, cardiopulmonary mortality, and long-term exposure to fine particulate air pollution. JAMA. 2002;287(9): 1132-41. Comment in: JAMA. 2002;288(7):830; author reply 830.

10. Versura P, Profazio V, Cellini M, Torreggiani A, Caramazza R. Eye discomfort and air pollution. Ophthalmologica. 1999;213(2):103-9.

11. Novaes P, do Nascimento Saldiva PH, Kara-Jose N, Macchione M, Matsuda M, Racca L, et al. Ambient levels of air pollution induce goblet-cell hyperplasia in human conjunctival epithelium. Environ Health Perspect. 2007;115(12):1753-6.

12. Novaes P, Saldiva PH, Matsuda M, Macchione M, Rangel MP, Kara-José N, et al. The effects of chronic exposure to traffic derived air pollution on the ocular surface. Environ Res. 2010 ; 110(4):372-4

13. Saxena R, Srivastava S, Trivedi D, Anand E, Joshi S, Gupta SK. Impact of environmental pollution on the eye. Acta Ophthalmol Scand. 2003;81(5):491-4.

14. WHO's global air-quality guidelines. Lancet. 2006;368(9544):1302.

15. Chen B, Kan H. Air pollution and population health: a global challenge. Environ Health Prev Med. 2008;13(2):94-101.

16. Hao J, Wang L. Improving urban air quality in China: Beijing case study. J Air Waste Manag Assoc. 2005;55(9):1298-305.

17. BrunekreefB, Holgate ST. Air pollution and health. Lancet. 2002;360(9341):1233-42.

18. Touloumi G, Katsouyanni K, Zmirou D, Schwartz J, Spix C, de Leon AP, et al. Short-term effects of ambient oxidant exposure on mortality: a combined analysis within the APHEA project. Air Pollution and Health: a European Approach. Am J Epidemiol. 1997;146(2):177-85.

19. Bell ML, McDermott A, Zeger SL, Samet JM, Dominici F. Ozone and short-term mortality in 95 US urban communities, 1987-2000. JAMA. 2004;292(19):2372-8.

20. Gipson IK. The ocular surface: the challenge to enable and protect vision: the Friedenwald lecture. Invest Ophthalmol Vis Sci. 2007;48(10):4390;4391-8.

21. Argueso P, Balaram M, Spurr-Michaud S, Keutmann HT, Dana MR, Gipson IK. Decreased levels of the goblet cell mucin MUC5AC in tears of patients with Sjogren syndrome. Invest Ophthalmol Vis Sci. 2002;43(4):1004-11.

22. Altshuller AP. Eye irritation as an effect of photochemical air pollution. J Air Pollut Control Assoc. 1977;27(11):1125-6.

23. Klopfer J. Effects of environmental air pollution on the eye. J Am Optom Assoc. 1989;60(10): $773-8$.

24. Okawada N, Mizoguchi I, Ishiguro T. Effects of photochemical air pollution on the human eyeconcerning eye irritation, tear lysozyme and tear pH. Nagoya J Med Sci. 1979;41(1-4):9-20.

25. The definition and classification of dry eye disease: report of the Definition and Classification Subcommittee of the International Dry Eye WorkShop (2007). Ocul Surf. 2007;5(2):75-92.

26. Methodologies to diagnose and monitor dry eye disease: report of the Diagnostic Methodology Subcommittee of the International Dry Eye WorkShop (2007). Ocul Surf. 2007;5(2): $108-52$.

27. Perry HD. Dry eye disease: pathophysiology, classification, and diagnosis. Am J Manag Care. 2008;14(3 Suppl):S79-87.

28. The epidemiology of dry eye disease: report of the Epidemiology Subcommittee of the International Dry Eye WorkShop (2007). Ocul Surf. 2007;5(2):93-107.

29. Lemp MA. Report of the National Eye Institute/Industry workshop on Clinical Trials in Dry Eyes. CLAO J. 1995:21(4):221-32.

30. Lemp MA, Hamill JR Jr. Factors affecting tear film break-up in normal eyes. Arch Ophthalmol. 1973;89(2):103-5.

31. Abelson MB, Ousler GW $3^{\text {rd }}$, Nally LA, Welch D, Krenzer K. Alternative reference values for tear film break up time in normal and dry eye populations. Adv Exp Med Biol. 2002;506(PtB):1121-5.

32. Norn MS. Semiquantitative interference study of fatty layer of precorneal film. Acta Ophthalmol (Copenh). 1979;57(5):766-74.

33. Mengher LS, Bron AJ, Tonge SR, Gilbert DJ. A non-invasive instrument for clinical assessment of the pre-corneal tear film stability. Curr Eye Res. 1985;4(1):1-7.

34. Goto E, Dogru M, Kojima T, Tsubota K Computer-synthesis of an interference color chart of human tear lipid layer, by a colorimetric approach. Invest Ophthalmol Vis Sci. 2003;44(11):4693-7.

35. Komuro A, Yokoi N, Kinoshita S, Tiffany JM, Bron AJ, Suzuki T. Assessment of meibomian gland function by a newly-developed laser meibometer. Adv Exp Med Biol. 2002;506(Pt A): 517-20.

36. Gendler SJ, Spicer AP. Epithelial mucin genes. Annu Rev Physiol. 1995;57:607-34.

37. Singh PK, Hollingsworth MA. Cell surface-associated mucins in signal transduction. Trends Cell Biol. 2006;16(9):467-76.

38. van Bijsterveld OP. Diagnostic tests in the Sicca syndrome. Arch Ophthalmol. 1969;82(1):10-4.

39. Bron AJ, Evans VE, Smith JA. Grading of corneal and conjunctival staining in the context of other dry eye tests. Cornea. 2003;22(7):640-50.

40. Nichols KK, Mitchell GL, Zadnik K. The repeatability of clinical measurements of dry eye. Cornea. 2004;23(3):272-85

41. Vitali C, Bombardieri S, Jonsson R, Moutsopoulos HM, Alexander EL, Carsons SE, Daniels TE, Fox PC, Fox RI, Kassan SS, Pillemer SR, Talal N, Weisman MH; European Study Group on Classifica- 
tion Criteria for Sjögren's Syndromeet al. Classification criteria for Sjogren's syndrome: a revised version of the European criteria proposed by the American-European Consensus Group. Ann Rheum Dis. 2002;61(6):554-8.

42. Hida RY, Nishiwaki-Dantas MC, Hida MM, Tsubota K. [Quantitative tear study using the red phenol test in the Brazilian population]. Arq Bras Oftalmol. 2005;68(4):433-7. Portuguese.

43. Rolando M, Baldi F, Calabria G. Tear mucus crystallization in children with cystic fibrosis. Ophthalmologica. 1988;197(4):202-6.

44. Felberg S, Cordeiro H, Sato EH, Martini Filho D, Nishiwaki-Dantas MC, Endo RM, et al. [Reproducibility of the classification of ocular ferning patterns in Sjogren's syndrome patients]. Arq Bras Oftalmol. 2008;71(2):228-33. Portuguese.

45. Martin DK. Osmolality of the tear fluid in the contralateral eye during monocular contact lens wear. Acta Ophthalmol (Copenh). 1987:65(5):551-5.
46. Farris RL. Tear analysis in contact lens wearers. CLAO J. 1986;12(2):106-11.

47. Iskeleli G, Karakoc Y, Aydin O, Yetik H, Uslu H, Kizilkaya M. Comparison of tear-film osmolarity in different types of contact lenses. CLAO J. 2002;28(4):174-6.

48. Martinez AJ, Mills MB, Jaceldo KB, Tio Fo, Aigbivbalu IB, Hilsenbeck SB, et al. Standardization of conjunctival impression cytology. Cornea. 1995;14(5):515-22.

49. Dart J. Impression cytology of the ocular surface-research tool or routine clinical investigation? Br J Ophthalmol. 1997:81(11):930. Comment on: Br J Ophthalmol. 1997:81(11):984-8.

50. Paschides CA, Stefaniotou M, Papageorgiou J, Skourtis P, Psilas K. Ocular surface and environmental changes. Acta Ophthalmol Scand. 1998;76(1):74-7.

51. Kjaergaard S. Assessment of eye irritation in humans. Ann N Y Acad Sci. 1992;641:187-98.

52. Tseng SC, Hirst LW, Maumenee AE, Kenyon KR, Sun TT, Green WR. Possible mechanisms for the loss of goblet cells in mucin-deficient disorders. Ophthalmology. 1984;91(6):545-52. 